\title{
Trilogi Kepemimpinan Ki Hajar Dewantara
}

\author{
Leo Agung $S$ \\ Universitas Sebelas Maret \\ leoagung@staff.uns.ac.id
}

\section{Article History}

received $1 / 9 / 2021$

\author{
revised $1 / 10 / 2021 \quad$ accepted 1/11/2021
}

\begin{abstract}
Leadership is an ability or strength within a person to lead and influence others in terms of work, with the aim of achieving predetermined targets. A leader is someone who is entrusted with being the chairman (head) of a system in an organization/institution/company. Thus, a leader must have the ability to guide and influence a person or group of people. In the Javanese concept, the ideal leadership is a leader who masters the science of Hasta Brata, namely a leader who has natural characteristics that represent a symbol of the wisdom and greatness of the Creator, namely; the nature of the Earth, the nature of the Sun, the nature of the Moon, the nature of the Ocean, the nature of the Stars, the nature of the Wind, the nature of Fire, and the nature of Water. From Hasta Brata, then by Ki Hajar Dewantara abstracted into the Leadership Trilogy, namely "Ing ngarsa sung tulodho, Ing madya mangun karso, Tut wuri handayani".
\end{abstract}

Keywords: leadership, hasta brata and leadership trilogy

\begin{abstract}
Abstrak
Kepemimpinan adalah sebuah kemampuan atau kekuatan di dalam diri seseorang untuk memimpin dan mempengaruhi orang lain dalam hal bekerja, dengan tujuan untuk mencapai target (goal) yang telah ditentukan. Adapun pemimpin adalah seseorang yang diberi kepercayaan sebagai ketua (kepala) dalam sistem di sebuah organisasi/ lembaga/perusahaan. Dengan demikian, maka seorang pemimpin harus memiliki kemampuan untuk memandu dan mempengaruhi seseorang atau sekelompok orang. Dalam konsep Jawa, kepemimpinan yang ideal adalah pemimpin yang menguasai ilmu Hasta Brata, yakni pemimpin yang memiliki sifat alam yang mewakili simbol kearifan dan kebesaran Sang Pencipta, yaitu; sifat Bumi, sifat Matahari, sifat Bulan, sifat Samudra, sifat Bintang, sifat Angin, sifat Api, dan sifat Air. Dari Hasta Brata tersebut, kemudian oleh Ki Hajar Dewantara disarikan ke dalam Trilogi Kepemimpinan, yakni "Ing ngarsa sung tulodho, Ing madya mangun karso, Tut wuri handayani".
\end{abstract}

Kata kunci: kepemimpinan, hasta brata dan trilogi kepemimpinan

Social, Humanities, and Education Studies (SHEs): Conference Series https://jurnal.uns.ac.id/shes

p-ISSN 2620-9284

e-ISSN 2620-9292 


\section{PENDAHULUAN}

Dalam khasanah budaya Jawa kuno, sedikitnya ada empat ajaran filsafat kepemimpinan. Keempat ajaran tersebut adalah (1) Hasta Brata (Delapan sifat Kepemimpinan), (2) Wulang Reh, (3) Tripana, dan (4) Dasa Darma Raja. Terkait dengan makalah kali ini, penulis menfokuskan pada Trilogi Kepemimpinan Ki Hajar Dewantara, sebab, kepemimpinan Ki Hajar Dewantara masuk dalam kawasan Hasta Brata (Suratno, 2006).

Konsep Hasta Brata muncul dalam cerita pewayangan Jawa dengan lakon Wahyu Makutharawa, yang mengisahkan tentang pemberian "wejangan" seorang pandita bernama Wiswamintra yang ditujukan kepada Sri Rama yang akan dinobatkan menjadi raja menggantikan ayahnya. Konon, ajaran hasta brata tersebut selalu dipedomani untuk dijadikan fatwa terhadap putra mahkota yang akan dinobatkan menjadi raja-raja Jawa. Hasta Brata terdiri atas kata hasta yang berarti delapan dan brata yang berarti sifat baik. Delapan sifat alam ini mewakili simbol kearifan dan kebesaran Sang Pencipta, yaitu; sifat Bumi, sifat Matahari, sifat Bulan, sifat Samudra, sifat Bintang, sifat Angin, sifat Api, dan sifat Air.

Generasi selanjutnya juga mengajarkan filsafat kepemimpinan sebagai terjemahan lebih lanjut dari IImu Hasta Brata ini, misalkan ilmu Manunggaling Kawula Gusti yang mengajarkan bagaimana filsafat kepemimpinan yang menyatu dengan rakyat tetapi dekat dengan Tuhan. Ajaran Manunggaling Kawula Gusti ini mencoba mengambil ajaran Hasta Brata menjadi satu intisari ajaran filsafat kepemimpinan (Harnowo, 2013).

Selain itu juga terdapat generasi filsafat kepemimpinan Jawa yang tergolong baru, yaitu Trilogi Kepemimpinan Ki Hajar Dewantara; Ing Ngarso Sungtulodho, Ing Madyo Mangunkarso dan Tut Wuri Handayani. Meskipun demikian, hampir semua ajaran filsafat kepemimpinan Jawa tersebut bersumber dari IImu Hasta Brata. Sebab ajaran Hasta Brata dapat dikatakan satu visi kepemimpinan yang relatif paling ideal dalam konsepsi ajaran filsafat kepemimpinan Jawa. Saking idealnya, seakan-akan tidak mungkin ada seorang pemimpin dapat menguasai kedelapan sifat alam tersebut. Oleh karena itulah kemudian para filsuf mencoba menurunkannya menjadi beberapa generasi ajaran filsafat kepemimpinan yang lebih spesifik (Harususilo, 2018).

\section{KAJIAN TEORI}

Pengertian kepemimpinan adalah sebuah kemampuan atau kekuatan di dalam diri seseorang untuk memimpin dan mempengaruhi orang lain dalam hal bekerja, dimana tujuannya adalah untuk mencapai target (goal) yang telah ditentukan. Sedangkan pengertian pemimpin adalah seseorang yang diberi kepercayaan sebagai ketua (kepala) dalam sistem di sebuah organisasi/ perusahaan. Dengan begitu, maka seorang pemimpin harus memiliki kemampuan untuk memandu dan mempengaruhi seseorang atau sekelompok orang. (Prawiro, 2020)

Secara umum, seorang pemimpin (leader) memiliki aura karismatik di dalam dirinya, memiliki visi misi yang jelas, mampu mengendalikan apa yang dipimpin, dan tentunya pandai dalam berkomunikasi. Pemimpin yang paling efektif adalah pemimpin yang mampu menyesuaikan gaya memimpin dan beradaptasi dengan berbagai situasi.

Kepemimpinan adalah sesuatu yang melekat pada diri pemimpin dalam bentuk kepribadian dan sifat-sifat tertentu seperti, cerdas, jujur, ulet, matang, tegas, cakap, supel, mampu, tangguh, dan sanggup menjadi seorang pemimpin. Kepemimpinan Menurut Lambert (2005), "Leadership and therefore the work of leadership as used within the definition of leadership capacity means reciprocal, purposeful learning together in community." (http://www.nscd.org/members/ jsd/lambert262.). Artinya, kepemimpinan dan kerja pemimpin dalam organisasi dapat berhasil dengan baik apabila adanya kerja sama yang baik dari semua pihak yang berkepentingan. Lebih lanjut Kristianty (2002:17), menyatakan kepemimpinan adalah suatu proses 
mempengaruhi seorang atau kelompok orang dalam situasi tertentu dan terjadi proses interaksi antara pemimpin dengan yang dipimpin dan situasi, secara sederhana proses kepemimpinan dapat dirumuskan melalui suatu formula: $L=F(I, f, s)$, di mana: $L=$ Leadership (kepemimpinan), $F=$ Function (fungsi), $I=$ leader (pemimpin), $f=$ follower (yang dipimpin), dan $s=$ situation (situasi). Dengan demikian kepemimpinan pada dasarnya melekat pada diri pemimpin dalam wujud kepribadian (personality), kemampuan (ability), kesanggupan (capability) mewujudkan kepemimpinan yang bermutu dan berkualitas, dari formula tersebut menunjukkan bahwa kepemimpinan akan dipengaruhi yang dipimpin. Menurut Adair, (2008 : 105), seorang pemimpin melaksanakan 4 (empat) peran yaitu: (1) menjadi panutan (moral personal), (2) menjadi perintis (moral visioner), (3) menjadi penyelaras (moral institutional), dan (4) menjadi pembudaya (moral cultural). Seorang pemimpin adalah orang yang mempunyai kecakapan dan kemampuan lebih dari orang lain, khususnya kecakapan dan kemampuan dalam kepemimpinan sehingga dapat mempengaruhi orang lain untuk bersama-sama melakukan aktifitas tertentu untuk mencapai tujuan bersama (Kartono, 2005:81). Pendapat tersebut menggambarkan bahwa figur seorang pemimpin dijadikan teladan dan panutan oleh mereka yang dipimpinnya, sehingga mereka yang dipimpin akan patuh dan mengikuti apa yang dilakukannya. Dengan demikian betapa besar tanggung jawab dan pengaruh seorang pemimpin, karena tindakannya, perilakunya, dan cara berpikirnya, bahkan kebiasaannya akan diikuti mereka yang dipimpinnya.

\section{A. Tipe Kepemimpinan}

Terkait dengan tipe kepemimpinan, maka menuurut Nawawi dan Hadari, 2014) ada beberapa tipe kepemimpinan sebagai berikut :

1. Kepemimpinan Klasik

Kepemimpinan klasik adalah kepemimpinan yang ditandai oleh sifat dominatif, direktif, otoritatif, dan para pengikut harus patuh/taat melaksanakan perintah pimpinan dan tertutup pertanyaan. Sifat-sifat tersebut ada karena pemimpinlah satu-satunya otoritas yang berhak menafsirkan kebenaran yang sah. Kerajaankerajaan dan negara-negara totalitarian pada umumnya menerapkan paradigma kepemimpinan klasik.

2. Kepemimpinan Berdasarkan Sifat

Pembawaan Teori ini meyakini bahwa pemimpin itu dilahirkan yang berarti pembawaan, bukan dipersiapkan/didikan.Sifat pembawaan pemimpin meliputi kualitas jiwa dan raga yang dapat digunakan untuk membedakan pemimpin dan pengikut. Contoh sifat pembawaan misalnya: kecerdasan intelektual, tubuh yang gagah dan tinggi, kepercayaan diri yg tinggi, dan tingkat energi.

3. Kepemimpinan Berdasarkan Perilaku

Teori ini meyakini bahwa perilaku pemimpin secara langsung mempengaruhi efektivitas kerja yang dipimpin, dan pemimpin dapat dipersiapkan/ dipelajari, bukan dilahirkan. Tiga jenis gaya perilaku pemimpin yaitu otoritarian, demokratik, dan pasif/pembiaran. Ketiganya dapat dipecahpecah lagi lebih rinci.

4. Kepemimpinan Kharismatik

Kepemimpinan karismatik adalah jenis kepemimpinan yang mengandalkan pada karisma seorang pemimpin. Karisma seorang pemimpin ditunjukkan oleh kewibawaan yang dimiliki oleh seorang pemimpin untuk mempengaruhi yang dipimpin. Kewibawaan bersumber pada aspek psikologis dan fisik seorang pemimpin.

5. Kepemimpinan Transaksional

Kepemimpinan transaksional adalah jenis kepemimpinan yang mengandalkan transaksi antara pemimpin dan yang dipimpin. Artinya, ada kesepakatan atau tawar menawar antara pemimpin dan yang dipimpin (politik dagang sapi). 
Pemimpin meminta yang dipimpin melakukan sesuatu dan yang dipimpin akan diberi imbal jasa jika yang dipimpin telah melaksanakan perintah sang pemimpin.

6. Kepemimpinan Situasional

Kepemimpinan situasional dapat diartikan bahwa keefektifan gaya kepemimpinan tertentu tergantung pada situasi. Jika situasi berubah, gaya kepemimpinan yang digunakan juga harus berubah. Jadi, tidak ada satu gaya kepemimpinan terbaik yang berlaku untuk semua situasi. Situasi adalah lingkungan yang berada di sekitar pemimpin, baik dalam bentuk fisik maupun non-fisik, yang perlu dipertimbangkan sebelum memilih jenis kepemimpinan tertentu. Situasi yang dimaksud dapat berupa: orang yang dipimpin, jenis pekerjaan, waktu, sistem/ struktur (politik, ekonomi, teknologi, sosial, dsb.), dan kultur. Dalam melakukan "interaksi" dengan yang dipimpin, seorang pemimpin selalu memilih "cara" memimpin yang paling tepat berdasarkan visi yang jelas, situasi yang dipimpin dan kondisi lingkungan yang mempengaruhinya. Dengan mempertimbangkan tiga hal ini, seorang pemimpin dapat menggunakan salah satu atau kombinasi cara-cara memimpin berikut: mengarahkan, memberi contoh, membimbing, mempengaruhi, mengkocing, memfasilitasi, mendukung, mendorong, memotivasi, mendelegasi, dan/atau cara lain yang tepat.

Menurut teori kepemimpinan situasional, perilaku pemimpin yang efektif juga tergantung pada tingkat kesiapan yang dipimpin. Kesiapan yang dimaksud adalah sejauhmana yang dipimpin memiliki kemampuan dan kesanggupan untuk menyelesaikan suatu tugas.

7. Kepemimpinan Visioner/ Transformasional

Kepemimpinan visioner/transformasional adalah kepemimpinan yang mengandalkan visi pemimpin sebagai inspirasi untuk mengarahkan pengikutnya. Tiga hal yang harus dilakukan oleh pemimpin transformasional: (1) menyadari perlunya perubahan, (2) menciptakan visi baru, (3) melembagakan perubahan.

8. Kepemimpinan Organik

Dalam kepemimpinan organik, pemimpin tidak menjadi figur sentral, akan tetapi kelompok secara keseluruhan menjadi kuncinya. Konsensus kelompok yang bisa menentukan siapa yang seharusnya menjadi pemimpin dan berapa lama. Jadi, kepemimpinan tak perlu bersarang pada individu tertentu, meskipun individu tersebut menduduki peran kepemimpinan untuk tujuan tertentu. Kompleksitas masalah yang dihadapi oleh organisasi membuat pemimpin sentral tunggal tidak lagi relevan. Perspektif dan kemampuan majemuk sangat diperlukan untuk memecahkan kompleksitas masalah yang dihadapi oleh suatu institusi/ organisasi.

Dari beberapa tipe kepemempinan ini seperti tersebut di atas, dalam praktek nya tergantung pada zamannnya. Terkait dengan kepemimpinan dewasa ini yang diharpkan adalah pemimpin yang visioner adalah pemimpin yang memiliki visi ke depan, demi kemajuan lembaga atau orgasisasi yang dipimpinnnya. Kepemimpinan visioner artinya kemampuan pemimpin dalam menciptakan, merumuskan, mengkomunikasikan, mengsosialisasikan dan mengimplementasikan pemikiranpemikiran ideal yang berasal darinya atau atau hasil interaksi antar anggota organisasi/lembaga lainnya. Orang dengan gaya atau tipe kepemimpinan ini akan selalu apa saja yang potensi bagi lembaga atau perusahaan yang tidak dilihat oleh orang lain. Setelah melihat potensi tersebut, ia akan menciptakan ide-idenya untuk dapat berfsaing secara kompetitif. Pemimpin yang visioner, menurut Sihombing (2021) memiliki ciri-ciri sebagai beriku: (1) pintar menjalin hubungan yang baik, (2) bisa membangun sebuah nilai, (3) bisa mengatasi hambatan (4) mampu berpikir dinamis, dan (5) mampu melakukan manajemen resiko.

Lebih lanjut terakit, dengan kepemimpinan Hasta Brata, menurut Ardiansyah (2014), (Suratno, 2006) adalah kepemimpinan yang memiliki delapan sifat alam 
mewakili simbol kearifan dan kebesaran Sang Pencipta, yaitu; sifat Bumi, sifat Matahari, sifat Bulan, sifat Bintang, sifat Air sifat Angin, sifat Api, dan sifat Samodra.

1. Brata yang kedua adalah BAWANA yang berarti bumi. Bumi diibaratkan sebagai ibu pertiwi. Sebagai ibu pertiwi, bumi memiliki peran sebagai ibu, yang memiliki sifat keibuan, yang harus memelihara dan menjadi pengasuh, pemomong, dan pengayom bagi makhluk yang hidup di bumi. Implementasinya adalah kalau sanggup menjadi pemimpin harus mampu mengayomi dan melindungi anak buahnya.

2. Brata yang pertama adalah SURYA yang berarti matahari. Sifat menerangi yang dimiliki oleh matahari dalam bahasa jawa dimaknai sebagai 'gawe pepadang marang ruwet rentenging liyan' yang berarti harus mampu membantu mengatasi kesulitan atau memecahkan problem-problem yang dihadapi oleh anak buahnya.

3. Brata yang ketiga adalah CANDRA yang berarti bulan. Implementasinya bagi pemimpin ialah pemimpin dalam memperlakukan anak buahnya harus dilandasi oleh aspek-aspek sosio-emosional. Pemimpin harus memperhatikan harkat dan mertabat pengikutnya sebagai sesama. Terhadap pengikutnya/anak buahnya harus menghormati sebagai sesama manusia. Dalam konsep Jawa hal ini disebut 'nguwongke'.

4. Brata keempat adalah KARTIKA yang berarti bintang. Bintang dapat menggambarkan dambaan cita-cita, tumpuan harapan, sumber inspirasi. Seorang pemimpin harus memiliki cita-cita yang tinggi, berpandangan jauh kedepan, pemberi arah, sumber inspirasi, dan tumpuan harapan.

5. Brata yang kelima adalah TIRTA yang berarti air. Seorang pemimpin harus mempunyai kemampuan untuk menyesuaikan diri dengan siapapun termasuk pengikutnya (adaptif). Air selalu mengalir ke bawah, artinya pemimpin harus memperhatikan potensi, kebutuhan dan kepentingan pengikutnya, bukan mengikuti kebutuhan atasannya.

6. Brata yang keenam adalah MARUTA, yang berarti angin. Secara alami angin memiliki sifat menyejukkan, angin membuat segar bagi orang yang kepanasan. Angin sifatnya sangat lembut. Seorang pemimpin harus bisa membuat suasana kepemimpinan sejuk, harmonis, dan menyegarkan.

7. Brata yang ketujuh adalah DAHANA, yang berarti api. Secara alami, api memiliki sifat panas, dan dapat membakar. Seorang pemimpim memiliki sifat pembakar semangat, pengobar semangat, dan memiliki peran sebagai motivator dan inovator bagi pengikutnya.

8. Brata yang kedelapan adalah SAMODRA, yang berarti lautan atau samudra. Pemimpin harus memiliki wawasan yang luas dan dalam, seluas dan sedalam samudra. Samudra juga bersifat menampung seluruh air dan benda-benda yang mengalir kearah laut. Seorang pemimpin harus memiliki sifat menampung semua kebutuhan, kepentingan, dan isi hati dari pengikutnya, serta pemimpin harus bersifat aspiratif.

\section{B. Trilogi Kepemimpinan Ki Hajar Dewantara}

Dalam perkembangnnya, tipe kepemimpinan dan kepemimpinan hasta brata di sarikan oleh Ki Hajar Dewantara dalam dunia pendidikan menjadi Trilogi, yang kemudian dikenal menjadi Trilogi Kepemimpinan Ki Hajar Dewantara.

\section{Saat Pemimpin di Depan atau "Ing Ngarso Sun Tulodho"}

Seorang pemimpin adalah panutan. Sebagai panutan, orang lain yang ada disekitarnya akan mengikuti. Seorang pemimpin harus mampu memberikan suri tauladan bagi orang - orang disekitarnya. Sehingga yang harus dipegang teguh oleh seseorang adalah kata suri tauladan. Dalam hal ini bisa dilihat betapa besarnya tanggungjawab moral seorang pemimpin, karena tindak-tanduknya, tingkah lakunya, cara berfikirnya, bahkan kebiasaannya akan cenderung diikuti 
orang lain. Untuk itulah maka saat berada di depan, pemimpin harus memberikan teladan, memberikan contoh. Disini tidak tercermin adanya atasan-bawahan, tetapi jelas menunjukkan siapa yang memimpin dan siapa yang dipimpin. Ini disebutkan oleh Ki Hajar dengan terminologi "ing ngarso sung tulodho", saat di depan seorang pemimpin harus memberi teladan. Artinya seorang yang berada di depan jika belum memberi teladan maka belum pantas menyandang gelar 'pemimpin' (Boentarsono, 2012: Sentono, 2019)

\section{Saat Pemimpin di Tengah atau "Ing Madyo Mbangun Karso"}

Seorang pemimpin yang berada di tengah-tengah orang-orang yang dipimpinnya, harus mampu menggerakkan, memotivasi, dan mengatur sumberdaya yang ada (empowering). Pada dasarnya setiap orang memiliki kemampuan untuk memotivasi diri sendiri (intrinsic motivation), sehingga ada ataupun tidak adanya stimuli tetap saja akan termotivasi. Hanya saja, kadar motivasi dari diri sendiri sering tidak stabil kehadirannya. Untuk itulah maka motivasi dari luar dirinya (extrinsic motivation) tetap sangat diperlukan. Disinilah seorang pemimpin dapat mengambil peran, kehadirannya membuat orang tergerak untuk bertindak, itulah pemimpin sejati (Boentarsono, 2012).

Ajaran kedua ini sarat dengan makna kebersamaan, kekompakan, dan kerjasama. Seorang pemimpin tidak hanya melihat kepada orang yang dipimpinnya, melainkan ia juga harus berada di tengah - tengah orang yang dipimpinnya (Sentana, 2019). Oleh karena itu, sangat tidak terpuji bila seorang pemimpin hanya diam dan tak berbuat apa - apa untuk anak buahnya, sehingga mereka berjalan sendiri-sendiri.Selain itu pemimpin harus kreatif dalam memimpin, sehingga orang yang dipimpinnya mempunyai wawasan baru dalam bertindak. Selain itu, seorang pemimpin harus melindungi segenap orang yang dipimpinnya.

\section{Saat Pemimpin di Belakang atau "Tut Wuri Handayani"}

Siapa bilang seorang pemimpin tidak boleh berada di barisan belakang? Pemimpin sejati diperlukan kehadirannya dibarisan belakang. Dari belakang seorang pemimpin dapat memberikan dorongan yang dipimpinya untuk terus maju. Pemimpin yang berada di barisan belakang harus pandai-pandai mengikuti barisan di depannya, agar konsisten gerakan dan arahnya , agar terjadi apa yang disebut goal cogruency, suatu keadaan di mana tujuan individu yang berada dalam suatu organisasi/lembaga konsisten dengan tujuan organisasi/lembaga. Tanpa goal congruency arah gerakan organisasi/lembaga menjadi berat karena banyaknya arah yang tidak sama dan mungkin justru saling berlawanan.(Sentono, 2019).

Ajaran kepemimpinan yang ketiga ini merupakan semboyan dari dunia pendidikan, yang tentunya mempunyai makna yang mendalam . Jika diartikan secara keseluruhan Tut Wuri Handayani memberi pengaruh, bertujuan untuk menciptakan pribadi yang mandiri dan tidak bergantung kepada orang lain (Suryamiharjo, 1986). Dengan ini diharapkan akan muncul generasi baru yang akan berani memimpin tanpa menunggu orang lain untuk memimpin. Adapun dorongan tersebut dapat berupa moral dan semangat kepada orang lain. Maka dari itu pendidikan mengambil semboyan ini , agar pendidikan menjadi sebuah perantara membentuk generasi mandiri dan tidak bergantung pada orang lain., menjadi pribadi yang mandiri dan kreatif.

\section{METODE}

Tulisan ini menggunakan metode kualitatif deskriptif. Teknik pengumpulan data yang digunakan ialah dengan pendekatan studi pustaka, yaitu pengumpulan dokumen berupa sumber-sumber buku, jurnal, dan media lainnya yang mendukung pembahasan dalam tulisan ini. Analisis data dengan menggunakan analisis kualitatif deskriptif. 


\section{HASIL DAN PEMBAHASAN}

Seorang pemimpin adalah motor penggerak yang senantiasa mempengaruhi, mendorong, dan mengarahkan orang-orang yang dipimpinnya, supaya mereka mau bekerja dengan penuh semangat dan kepercayaan dalam rangka mencapai tujuan yang telah ditetapkan. Oleh karena itu, pemimpin seharusnya memandu, memantau, memberikan motivasi, atau membangun motivasi kerja, membimbing dan membangun jaringan yang lebih baik, sehingga mereka yang dimpin dalam rangka membawa kemajuan organisasi/lembaga yang dipimpinnnya.

Dalam kepemimpinan hasta brata, astra brata tidak hanya diajrkan melalui sastra tulis, melainkan juga melalui seni pertunjukan. Terdapat dua jenis tradisi seni pertunjukan yang menjadi media pertunjukan yakni (1) berupa naskah, dan (2) seni pertunjukan dalam bentuk pagelaran wayang kulit (Suratno, 2006: 53). Jika dahulu ajaran hastabrata diperuntukan para raja, atau penguasa yang akan memipim sebuah kerajaan, namun karena pergesaran waktu ajaran hastabrata telah menjadi ajaran bagi para pemimpin masa sekarang. Implikasinya seorang pemimpin mulai pemimpin di tingkat pusat sampai daerah perlu meledani watak delapan atau sifat delapan benda alam. Artinya setiap seseorang pemimpin hendaknya juga mampu menjadi matahari, mampu menjadi bulan, mampu menjadi bintang, mampu menjadi bumi, mampu menjadi air, mampu menjadi api, mampu menjadi angin dan mampu menjadi samudra bagi orang yang dimpinnnya.

Dalam perkembangnya juga, pola kepemimpinan hastabrata juga memumculkan pola kepemimpinan baru, yakni pola kepemimpinan Ki Hajar Dewantara yang dikenal dengan nama Trilogi Kepemimpinan Ki Hajar Dewantara. Ki Hadjar Dewantara pada tanggal 28 November 1959 ditetapkan sebagai "Pahlawan Nasional". Tanggal 16 Desember 1959, pemerintah menetapkan tanggal lahir Ki Hadjar Dewantara tanggal 2 Mei sebagai "Hari Pendidikan Nasional" berdasarkan keputusan Presiden RI Nomor: 316 tahun 1959.12 Sebagai tokoh nasional yang dihormati dan disegani baik oleh kawan maupun lawan, Ki Hadjar Dewantara sangat kreatif, dinamis, jujur, sederhana, konsisten, konsekuen dan berani. Wawasan beliau sangat luas dan tidak berhenti berjuang untuk bangsanya hingga akhir hayat. Perjuangan beliau dilandasi dengan rasa ikhlas yang mendalam, disertai rasa pengabdian dan pengorbanan yang tinggi dalam mengantarkan bangsanya ke alam merdeka (Haryadi, 1989 : 132)

Trilogi Kepemimpinan Ki Hajar Dewantaar yang dimaksud adalah Ing ngarsa sung tulodho, Ing madya mangun karso, Tut wuri handayani”. Ing Ngarso Sung Tulodho yang berarti bahwa seseorang pemimpin harus mampu melalui sikap dan perbuatannya menjadikan dirinya pola panutan dan di ikuti orang yang dipimpinnya (Hasibuan, 2008: 170). Hasil implementasi Ing Ngarso Sung Tuladho. Secara umum yang dimaksud keteladanan yaitu setiap saat atau setiap kesempatan menjadi contoh atau suri tauladan. Pamong senantiasa diharapkan untuk selalu bertutur kata dan bertingkah laku baik untuk menjadi panutan bagi orang yang dipimpinnya (Boentarsono, 2012: 31).

Ing Madyo Mangun Karso artinya seorang pemimpin harus mampu membangkitkan semangat berswakarsa dan berkreasi pada orang-orang yang dibimbingnya (Hasibuan, 2008: 170). Hal ini sejalan dengan konsep kepemimpinan secara umum, yakni pemimpin idealnya dapat menyatupadukan orang-orang yang berbeda-beda motivasinya tersebut dengan motivasi yang sama.

Tut Wuri Handayani berarti bahwa seseorang pemimpin harus mampu mendorong orang-orang yang diasuhnya agar berani berjalan didepan dan sanggup bertanggung jawab (Hasibuan, 2008: 170). Hasil implementasi Tut Wuri Handayani di dunia pendidikan kepala sekolah mampu memberikan dukungan moril kepada guru dalam mengabdi sebagai pendidik, sehingga hal ini juga menginspirasi guru untuk mendukung siswa dari belakang agar mereka berhasil dalam menempuh pendidikannya. Salah satu tugas pokok pimpinan memang memberikan inspirasi dan 
mendorong anggota-anggotanya bekerja seefektif dan seefisien mungkin. Jika dihubungkan dengan konteks kepemimpinan guru, maka guru harus dapat menginspirasi siswa agar mampu berprestasi (Handayaningrat, 1999: 70).

Dengan demikian konsep "tut wuri handayani" (di belakang memberi bimbinganmomong) dan "ing madyo mangun karso" (di tengah memberi semangat-among) tidak akan berjalan optimal bila tidak ada "ing ngarso sung tulodho", yaitu pemimpin (pamong) yang bertindak sebagai contoh bagi anggotanya. Memberi contoh, ngemong, tidak hanya secara kemampuan tapi juga secara etika dan moral (Harususilo, 2018).

\section{SIMPULAN}

Pada dasarnya setiap orang memiliki jiwa kepemimpinan di dalam dirinya, meskipun beberapa orang memang lebih dominan. Dalam penerapannya, setiap orang memiliki gaya kepemimpinan yang unik sesuai dengan karakter dan situasi tertentu. Seharusnya memahami kepemimpinan tidak hanya sebagai wacana saja, tetapi dapat diterapkan di lingkungan kerja demi membentuk budaya organisasi yang baik. Dengan gaya kepemimpinan yang dimiliki, diharapkan para anggota atau karyawan akan mengikuti langkah seorang pemimpin yang menginspirasi. Sesuai dengan gaya kempeimpinan Ki Hajar Dewantara di dunia pendidikan, yang mensarikan ajaran hasta brata, maka seorang pemimpin yang baik di depan memberikan contoh, di tengah membangun karsa dan di belakang memberikan semangat.

\section{DAFTAR PUSTAKA}

Adair, J. (2008).Kepemimpinan yang Memotivasi. Judul Asli: Leadership and Motivation. Penerjemah: Fairano Ilyas. Jakarta: PT Gramedia Pustaka Utama.

Ardiansah, Rhesa.(2017) Ilmu Hasta Brata: Refleksi Model Kepemimpinan Jawa Sebagai Solusi Tantangan Zaman, dalam https://www.kompasiana.com/rhesaardy/59e18c12147f9624645efd52/ilmu-hastabrata-refleksi-model-kepemimpinan-jawa-sebagai-solusi-tantangan-zaman. 14 Oktober 2017.

Benedictus K dan Sri A W. (2016). "Pola kepemimpinan Ki Hadjar Dewantara". Jurnal Managemen Pendidikan” - Vol. 11, No. 2, Januari 2016: 18-29.

Boentarsono,Ki B. (2012), Taman Siswa: Badan Perjuangan Kebudayaan dan Pembangunan Masyarakat. Yogyakarta: Aditya Media.

Budiman, Riadi. (2012). "Analisis Gaya Kepemimpinan yang Mempengaruhi Kepuasan dan Motivasi Kerja Karyawan", Jurnal ELKHA, Fakultas Teknik, Universitas Tanjung Pura.

Handayaningrat, Soewarno. (1999). Pengantar Studi Ilmu Administrasi dan Manajemen. Jakarta: Haji Masagung.

Hani, H, (2001). Manajemen. Edisi ke-2. BPFE. Yogyakarta.

Harnowo, Ahmad Jazuli. (2013). Memahami Konsep Manunggaling Kawulo Gusti secara Sederhana - http://www.Kompasiana.com, diunduh, 14 Oktober 2021.

Hariyadi, Ki (1989). Ki Hadjar Dewantara sebagai Pendidik, Budayawan, Pemimpin Rakyat dalam Buku Ki Hadjar Dewantara dalam Pandangan Para Cantrik dan Mentriknya. Yogyakarta: MLTS.

Harususilo, Yohanes Enggar. (2018). Kepemimpinan Versi Ki Hajar Dewantara. dalam https://edukasi.kompas.com/read/2018/06/04/08553811/kepemimpinan-versikihadjar-dewantara?, diakses 1 Oktober 2021

Hasibuan, Malayu, SP. (2008). Manajemen sumber daya manusia. Jakarta: Bumi Aksara.

Katono, Kartini. (2005). Pemimpin dan Kepemimpinan. Jakrta : Rajawali Press.

Nawawi, Hadari, dan Hadiri, Martini. (2014). Kepemimpinan yang Efektif. Yogyakarta : Gadjah Mada University Press 
Prawiro, M. (2020). Pengertian Kepemimpinan: Tujuan, Fungsi, dan Gaya Kepemimpinan, dalam https://www.maxmanroe.com/vid/organisasi/pengertiankepemimpinan.html,24/06/2020 diakses 14 Oktober 2021

Siagian, S.P. (2003).Organisasi Kepemimpinan dan Perilaku Administrasi. Jakarta : Gunung Agung.

Sentono, Tarto. (2019). Pengembangan Model Kepemimpinan Berbasis Trilogi Kepemimpinan Ki Hajar Dewantara. Klaten : Citta Gracia .

Sihombing, Helda. (2021). Memahami Makna Kepemimpinan yang Visioner dan CiriCirinya, dalam lifepal.co.id) 11 Mei 2021, diakses, 1 Oktober 2021.

Suratno, Pardi . (2005). Sang Pemimpin Menurut Asthabrata, Wulang Reh, Tripama, Dasa Darma Raja. Yogyakarta : Tiara Wacana.

Suryamiharjo. (1986). Ki Hajar Dewantara dan Taman Siswa Dalam Sejarah Indoensia. Jakrta : Sinar Harapan.

Wijayanti, Wenny. (2019). "Implementasi Trilogi Kepemimpinan (Ki Hadjar Dewantara) di Madrasah Tsanawiyah".Media Manajemen Pendidikan (MMP).Volume 2 No. 2 Oktober 2019 p-ISSN: 2622-772X e-ISSN: 2622-3694 